Weed Science 2017 65:128-140

(C) Weed Science Society of America, 2016

\title{
Diversity and Spatial Heterogeneity of Weed Communities in a Sugarcane Cropping System in the Dry Tropics of Costa Rica
}

\begin{abstract}
Ramon G. Leon, Renán Agüero, and Diego Calderón*
Weed diversity, structure, and distribution within and outside agricultural fields affect not only ecological processes but also weed management strategies. We studied how areas managed differently within and outside the field determine weed communities in a sugarcane cropping system in the dry tropics of Costa Rica. A total of 120 weed species were detected, which was similar to surveys conducted in subtropical and temperate conditions. Weed species richness was highest in undisturbed field borders and lowest in rows and furrows. The area where tractors turn within the field (turn area) had similar richness compared with the borders, despite being one of the most disturbed management areas studied. The most predominant weed species were divided between generalists and species that exhibited clear preferences for management area or soil texture. Soil texture was more important for determining weed community structure than management area when considering weed species affecting weed control decisions. The results indicated that disturbance in the management area and, especially, weed control practices are critical factors affecting weed diversity, but availability of resources for weed growth such as nutrients, soil moisture, and light can mitigate some of the limitations imposed by weed control on weed diversity, especially in the turn area. Differences in weed communities between management areas within fields indicated the existence of conditions that favor key weed species, and this information can be used to anticipate their population growth and help determine when and where more intensive control should be implemented.
\end{abstract}

Nomenclature: sugarcane, Saccharum officinarum L.

Key words: control, disturbance, diversity, habitat, soil, texture, tropicsweed.

Weed populations are commonly considered negative organisms in agricultural fields because of their potential to reduce crop yields and interfere with production practices (Mortensen et al. 2012; Storkey and Cussans 2007). However, in recent years, weed communities have been recognized as important components of agroecosystems that could help maintain biodiversity by contributing directly to plant diversity. Moreover, weeds also provide habitats for other organisms such as invertebrates and soil microbial communities (Hawes et al. 2010; Marshall et al. 2003; Musters et al. 2009; Norris and Kogan 2000; Petit et al. 2011). This dual role represents a challenging trade-off that should be resolved to ensure minimal impacts on crop productivity, which unavoidably requires weed control, while preserving weed diversity and therefore promoting ecological processes occurring within fields (Storkey and Cussans 2007). This apparent contradiction could be

\footnotetext{
DOI: 10.1614/WS-D-16-00066.1

*First author: Assistant Professor, West Florida Research and Education Center and Agronomy Department, University of Florida, Jay, FL 32565; second and third authors: Professor and Former Research Assistant, Programa de Malezas, Estación Experimental Agrícola Fabio Baudrit Moreno, Facultad de Ciencias Agroalimentarias, Universidad de Costa Rica, San José, Costa Rica. Corresponding author's E-mail: rglg@ufl.edu
}

dealt with by taking advantage of spatial distribution of weed communities and potential microhabitats created by crop management practices.

Weed distribution is directly dependent on dispersal and disturbance patterns, but the successful colonization, establishment, and growth of weed populations are commonly dependent on resource availability. For example, where water is limiting, weed populations develop more in areas where water is directly provided via irrigation (Sutton et al. 2006). Similarly, fertilizer placement can affect the distribution and density of weed populations. Blackshaw et al. (2004) demonstrated that broadcast applications tend to favor more widely spread and denser weed populations than banded or injected fertilization. Another critical factor affecting weed diversity and distribution is disturbance by weed control practices (Kleijn and Snoeijing 1997). Thus, frequent elimination of vegetation via mechanical or chemical means is perhaps the strongest filter for weed survival in agroecosystems (Kleijn and van der Voort 1997).

Sugarcane cropping systems in the dry tropics are useful to study how heterogeneity in resource availability and disturbance affect weed community structure and distribution within and outside fields. In sugarcane cropping systems, the landscape is divided into areas that are used for irrigation and

128 • Weed Science 65, January-February 2017 
drainage in which water availability is high and concentrated. Moreover, due to the spatial arrangement of fields in the landscape, some areas remain practically undisturbed throughout the year. Within fields there are key differences that might affect weed distribution and management. For example, furrows are used for surface irrigation and raised beds are maintained to favor sugarcane root growth. These two management areas provide very different conditions for plant growth, so it might be possible that their weed populations could be controlled differently. Additionally, there is great concern about biodiversity loss in the tropics, and efforts to contribute to biodiversity preservation in this ecoregion are a priority (Olson et al. 2001; Perfecto and Vandermeer 2010). Several researchers have hypothesized that plant diversity at the landscape level can favor plant diversity in agricultural fields (Bohan and Haughton 2012; José-María et al. 2010; Solé-Senan et al. 2014). Therefore, it is possible that despite restrictions imposed by agricultural practices, the high plant diversity present in the dry tropics helps maintain higher plant diversity in agricultural fields compared with agroecosystems in other latitudes and ecoregions.

We hypothesized that weed diversity in sugarcane fields is negatively related to disturbance frequency and intensity (Hawes et al. 2010), whereas it is positively associated with resource availability, specifically water. However, because weed species differ in growth requirements and tolerance to disturbance, we hypothesized that areas within sugarcane fields differing in production practices (i.e., management areas) would have distinct weed community composition, which would allow differentiated weed control strategies. Also, we proposed that weed diversity in the dry tropics would be higher than in cropping systems in other latitudes and ecoregions.

\section{Materials and Methods}

Study Site. A survey was conducted in Cañas, Guanacaste, Costa Rica, in approximately 9,000 ha of sugarcane fields surrounding Ingenio Taboga (i.e., sugarcane mill; $10.350^{\circ} \mathrm{N}, 85.178^{\circ} \mathrm{W}$ ). The surveyed area was mainly devoted to continuous sugarcane production in cycles that varied from 4 to $8 \mathrm{yr}$ between sugarcane planting and the last ratoon crop, and the fields had been under sugarcane production for more than 12 yr. Holdridge (1982) defined this region as a tropical dry forest, which has two defined seasons: a rainy season (mid-May to the end of November) and a dry season (December to May). The average temperature is $28 \mathrm{C}$, and the maximum and minimum temperatures are 32 and $23 \mathrm{C}$, respectively. Annual mean rainfall is $1,600 \mathrm{~mm}$, but rainfall distribution during the rainy season is not uniform and is characterized by isolated intense rainfall events.

A total of 82 and 75 fields were sampled in 1998 and 2000, respectively. The selected fields were grouped based on soil texture for a total of 20 and 17 clay fields (montmorillonite was the predominant clay type in the study area), 27 and 25 clay loam fields, 18 and 17 loam fields, and 17 and 16 sandy loam fields in 1998 and 2000, respectively. Sampling was conducted from January to June in both years following the first irrigation of each field. Fields were randomly selected based on the database of the sugarcane mill, excluding fields that needed to be renovated (i.e., elimination of old plants and replanting with vegetative seed from young plants) during the sampling years. Additionally, sampling considered soil texture to ensure that the number of fields in a given soil texture category represented at least $20 \%$ of the total sampling. Fields were mainly rectangular in shape (Figure 1) and had an average size of 10 ha, although field areas ranged from 2 to 21 ha. Weed control and agronomic practices were based on the same criteria for all fields (Table 1).

Weed Sampling and Identification. Each field was divided into six management areas: row, furrow, irrigation canal, drainage, turn area, and border (Figure 1). The row extended from the center of the sugarcane-planting row to half the height of the planting bed $(0.6 \mathrm{~m})$. The furrow was the bottom half of the planting bed and included the area where the water moves during surface irrigation $(0.6 \mathrm{~m})$.

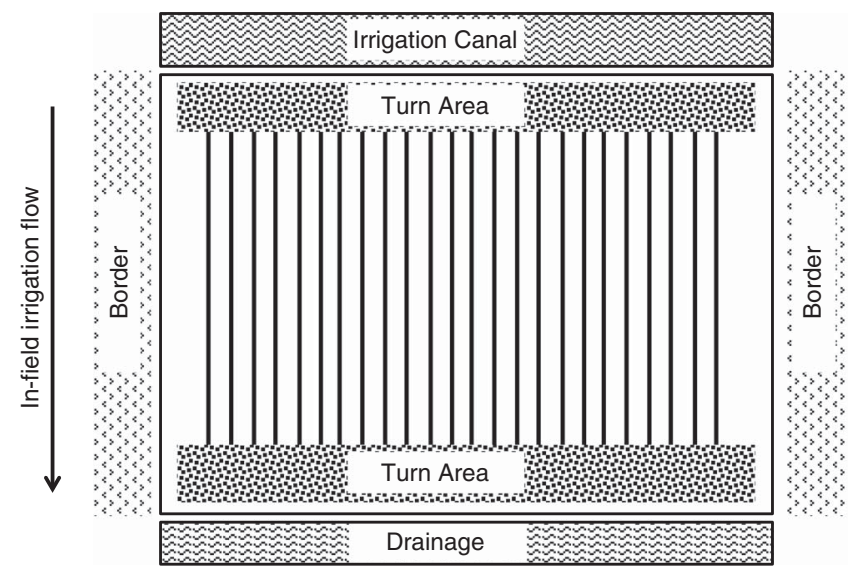

Figure 1. Distribution of management areas in sugarcane fields. Vertical black lines within the field indicate the rows and the spaces between them represent furrows. 
Table 1. Type and frequency of weed control and fertilization practices implemented in six different management areas in a sugarcane cropping system in Cañas, Guanacaste, Costa Rica.

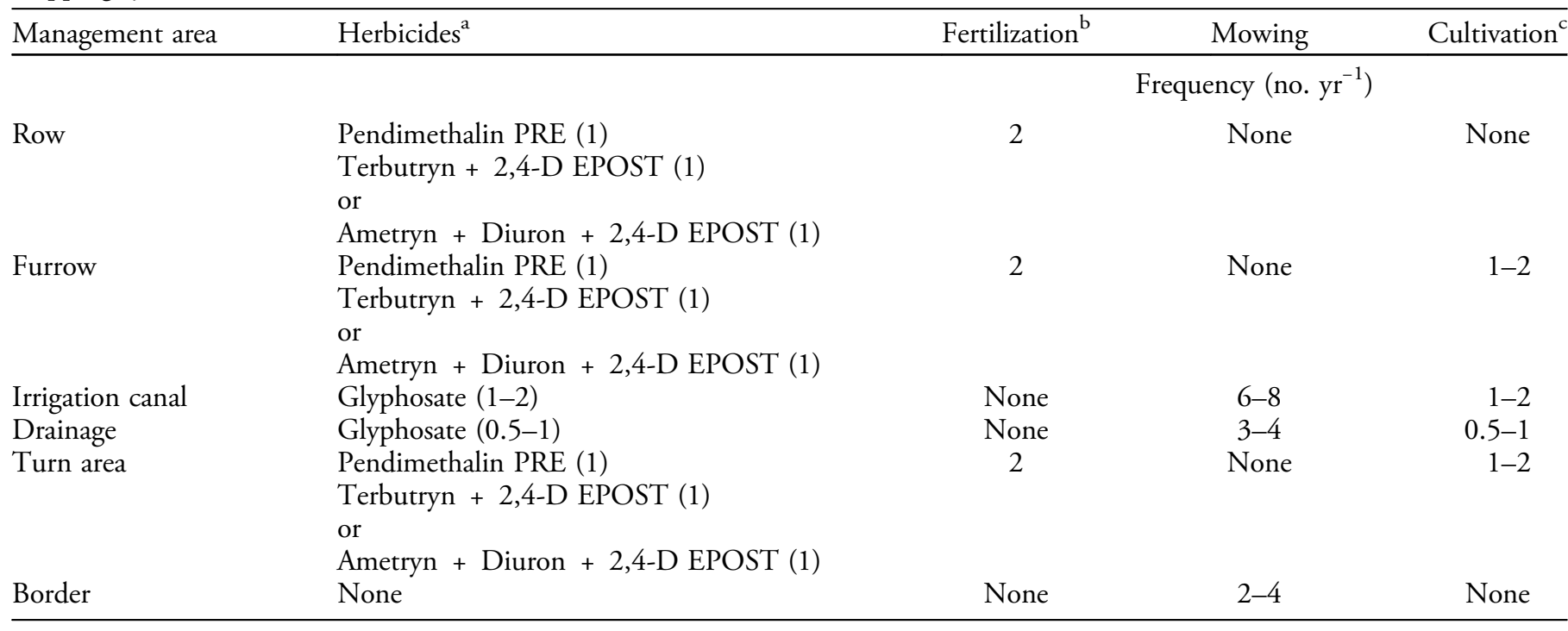

${ }^{a}$ Numbers within parentheses indicate the frequency of herbicide application per year.

${ }^{\mathrm{b}}$ Fertilization was based on soil analysis and optimum levels based on recommendations by Bertsch (1995).

'Tractors were used for cultivation, fertilization, and herbicide application.

Weeds growing in the row and furrow received herbicide and fertilizer applications and intense shading from the sugarcane canopy (Table 1). The furrow also received cultivation before irrigation. The irrigation canal was located at the entrance of the field perpendicular to the planting rows and covered an area that was $2 \mathrm{~m}$ wide. The sampling area included the inside of the canal and $0.5 \mathrm{~m}$ on each side. The drainage was the ditch (same dimensions and sampling area as irrigation canal) located at the end of the field perpendicular to the planting rows and parallel to the irrigation canal, and its function was to prevent flooding at the end of the field during surface irrigation and intense rainfall events. The irrigation canal area was mown every 6 to $8 \mathrm{wk}$ and, at least once per year, vegetation was removed mechanically to reshape the canal (Table 1). Additionally, there was high variation in soil moisture because of intermittent flooding and drying during the irrigation season. The drainage had the same types of disturbance as the irrigation canal, but canal reshaping was done only once a year or every other year, and mowing was done three to four times a year (Table 1). The space within the field immediately next to the irrigation canal or the drainage where the sugarcane row started and where tractors turn around when conducting practices such as fertilization, cultivation, and pesticide applications was designated as the turn area. This area varied in width, but in most fields it was approximately $5 \mathrm{~m}$ wide on both sides of the field. Weeds growing in the turn area were exposed to the same or slightly lower rates of herbicide and fertilizer applications and irrigation and cultivation intensity as those growing in the row and furrow, but the turn area had more soil compaction and light penetration through the sugarcane canopy than the rows and furrows. The two sides of the field parallel to the outermost sugarcane rows were designated as the border. Borders were 2 to $6 \mathrm{~m}$ wide and were characterized by minimal disturbance, which was limited to mowing two to four times a year (Table 1).

For each field, $3 \mathrm{wk}$ after the first surface irrigation and before herbicide application, each management area was sampled in four different observation points that were evenly spaced depending on the size of the field to determine which weed species were present and their relative ground cover. In each observation point, the surveyor looked for weed species present in $20 \mathrm{~m}^{2}$ (mostly 10 by $2 \mathrm{~m}$, although length was increased proportionally if the width of the sampling area was less than $2 \mathrm{~m}$, to maintain a constant area), avoiding overlap with other management areas. The readings from the four sampling points within each management area were pooled. Preliminary sampling indicated that this sampling strategy allowed identification of the majority $(>90 \%)$ of weed species present in each area in a timely fashion. Weed species cover was visually determined using an index with a 0 to 5 scale in which $0=$ absence, $1=<1 \%$ 
of the sampled area was cover with the weed species, $2=1$ to $5 \%$ cover, $3=6$ to $30 \%$ cover, $4=31$ to $66 \%$, and $5=67$ to $100 \%$ cover (Soto and Agüero 1992). Weed species were identified in situ, but in cases in which this was not possible, destructive samples of flowering specimens were collected. For unidentified species that only had individuals at the seedling stage, seedlings were transplanted to pots and maintained under controlled conditions until flowering, when identification was made. The identification of collected material was conducted in collaboration with the National Herbarium of the National Museum of Costa Rica.

Data Analysis. Weed species richness $(S)$ was estimated by counting the total number of weed species recorded in each management area or soil type. The importance of a weed species within the weed community for a given management area or soil type was determined using a frequency cover index (FCI) (Rojas 1995):

$$
\mathrm{FCI}=\frac{m_{i} *\left(\sum c_{i j}\right)}{n^{2}}
$$

in which $m$ is the number fields where species $i$ was detected, $c$ is the cover recorded for species $i$ in a given field $j$, and $n$ is the total number of sampled fields. Additionally, farm managers and agronomists responsible for the sampled fields were asked which species and what level of cover of those species most influenced their decision making for weed control. Their responses were compared later with observed FCI values to determine what fraction of the total weed richness influenced weed management decisions.

We evaluated management area preference of the most predominant weed species based on FCI ranking. Because occurrence is not necessarily an accurate indicator of habitat preference, we compared the cover of selected species among management areas and soil types only for fields in which these weeds were detected. This analysis was done under the assumption that a habitat that meets weed species requirements will favor the development of denser populations and greater ground cover.

For weed richness and cover per individual selected species, results were analyzed with ANOVA using PROC MIXED of SAS (SAS Institute, Cary, NC). Main effects were year, management area or soil type, and year by management area or year by soil type interactions. A Tukey-Kramer honestly significant difference test $(\alpha=0.05)$ was used for mean separation. Additionally, canonical correspondence analyses (CCA) were conducted with CANOCO (version 4.53, Wageningen University, Netherlands) to determine weed community structure and possible associations with management areas and soil types, using weed species detection frequency as the main variable. CCA was done for the top $25 \%$ weed species based on FCI, because we were interested in identifying differences in weed community structure that could justify differentiated weed control tactics emphasizing management areas that directly affect sugarcane yield. Farm managers and agronomists stated that rare species do not influence their decision-making process, so these species were not included in the CCA. Monte Carlo permutation tests were conducted with a minimum of 1,000 permutations to determine the significance $(\alpha=0.05)$ of the canonical axes. Biplots were created based on the two canonical axes that significantly explained most of the variability observed.

\section{Results and Discussion}

Total Weed Species Richness. Combining the results of the surveys conducted in 1998 and 2000, a total of 120 weed species were detected (Table 2), which was higher than previous reports in other tropical and subtropical regions. For example, in rice fields managed as monoculture in Cambodia, Kamoshita et al. (2014) reported 76 weed species in an area of 950 ha. Similarly, in northern Laos, de Rouw et al. (2014) recorded 75 species in a survey also conducted in rice fields. However, studies in subtropical and several temperate regions have identified weed diversity levels similar to our results. For instance, sampling at a larger scale (approximately $7,000 \mathrm{~km}^{2}$ ) in an area with intensive annual crop production including maize, soybean, and winter wheat in the Rolling Pampa region in Argentina, Poggio et al. (2013) identified 143 arable plant species. Gaba et al. (2010) reported 135 weed species in winter wheat fields in central western France, while Cordeau et al. (2012) and Trichard et al. (2013) reported 101 and 93 weed species, respectively, in agricultural fields in central and eastern France. Armengot et al. (2011) recorded 122 weed species in northeastern Spain in an area predominantly comprised of arable land for cereal production. Although tropics tend to be rich in biodiversity (Mittermeier et al. 1998), we did not observe dramatic differences in weed diversity in the studied sugarcane cropping system compared with studies from other ecoregions, which suggests that 
Table 2. Frequency cover index (FCI) of species present in a sugarcane cropping system in 1998 and 2000 in Cañas, Guanacaste, Costa Rica.

\begin{tabular}{|c|c|c|c|c|c|}
\hline Species & \multicolumn{2}{|c|}{$\mathrm{FCI}^{\mathrm{a}}$} & Species & \multicolumn{2}{|c|}{$\mathrm{FCI}^{\mathrm{a}}$} \\
\hline Ageratum conyzoides L. & - & - & Hyparrhenia rufa (Nees) Stapf & 0.06 & 0.10 \\
\hline Amaranthus hybridus $\mathrm{L}$. & - & - & Ipomoea trifida (Kunth) G. Don & 0.14 & 0.08 \\
\hline Amaranthus spinosus $\mathrm{L}$. & 0.06 & 0.24 & Ischaemum rugosum Salisb. & - & - \\
\hline Amaranthus viridis $\mathrm{L}$. & - & - & Isocarpha atriplicifolia (L.) R. Br. ex DC. & - & - \\
\hline Baltimora recta $\mathrm{L}$. & 0.20 & 0.01 & Leptochloa filiformis (Pers.) P. Beauv. & 0.01 & 0.22 \\
\hline Blechum brownei fo brownei & 0.01 & 0.04 & Leptochloa mucronata (Michx.) Kunth & - & - \\
\hline Boerhavia erecta L. & - & - & Leptochloa scabra Nees & 0.04 & - \\
\hline Brachiaria mutica (Forssk) Stapf & 0.41 & 0.01 & Limnocharis flava (L.) Buchenau & - & 0.01 \\
\hline Canna glauca L. & - & - & Ludwigia erecta (L.) H. Hara & - & 0.02 \\
\hline Caperonia palustris (L.) A. St.-Hil. & 0.94 & 0.94 & Mecardonia procumbens (Mill.) Small & - & 0.01 \\
\hline Chamaesyce dioica (Kunth in H. B. K.) Millsp. & - & - & Merremia quinquefolia (L.) Hallier $\mathrm{f}$. & 0.01 & - \\
\hline Chamaesyce hirta (L.) Millsp. & 0.06 & 0.03 & Merremia umbellata (L.) Hallier $\mathrm{f}$. & 0.02 & 1.53 \\
\hline Chamaesyce hyssopifolia (L.) Small & 0.10 & 0.02 & Mimosa pudica L. & - & - \\
\hline Chloris inflata Link & 0.18 & 0.37 & Mollugo verticillata $\mathrm{L}$. & 0.14 & 0.09 \\
\hline Chloris radiata (L.) Sw. & - & - & Momordica charantia $\mathrm{L}$. & - & 0.04 \\
\hline Chromolaena odorata (L.) R. M. King \& H. Rob. & - & - & Mucuna sp. & - & - \\
\hline Cissus verticillata (L.) Nicolson \& C. E. Jarvis & - & - & Nelsonia canescens (Lam.) Spreng. & - & 0.87 \\
\hline Cleome spinosa Jacq. & - & - & Oryza latifolia Desv. & - & 0.98 \\
\hline Cleome viscosa $\mathrm{L}$. & 0.28 & 0.77 & Panicum maximum Jacq. & - & 0.31 \\
\hline Commelina diffusa Burm. F. & 1.28 & 2.02 & Panicum pilosum Sw. & - & - \\
\hline Corchorus orinocensis Kunth & 0.04 & - & Paspalum virgatum $\mathrm{L}$. & - & - \\
\hline Crotalaria retusa $\mathrm{L}$. & - & - & Passiflora foetida $\mathrm{L}$. & - & 0.02 \\
\hline Croton argenteus $\mathrm{L}$. & - & 0.29 & Pennisetum purpureum Schumach. & - & - \\
\hline Cyperus rotundus $\mathrm{L}$. & 18.71 & 29.99 & Ricinus communis $\mathrm{L}$. & - & 0.13 \\
\hline Cyperus surinamensis Rottb. & - & 0.01 & Rottboellia cochinchinensis (Lourd.) Clayton & 16.81 & 36.25 \\
\hline Desmanthus virgatus (L.) Willd. & 0.01 & - & Ruellia nudiflora (Engelm. \& A. Gray) Urb. & - & - \\
\hline Desmodium sp. & - & - & Scoparia dulcis $\mathrm{L}$. & - & 0.01 \\
\hline Digitaria bicornis (Lam.) Roem. \& Schult. & 0.03 & - & Sida acuta Burm. f. & - & - \\
\hline Digitaria ciliaris (Retz.) Koeler & 0.12 & 0.29 & Sida rhombifolia L. & - & 0.02 \\
\hline Dyschoriste valeriana Leonard & - & - & Sida urens L. & - & - \\
\hline Echinochloa colona (L.) Link & 0.13 & 0.41 & Solanum americanum Mill. & - & - \\
\hline Echinodorus paniculatus Micheli & - & - & Sonchus oleraceus L. & - & - \\
\hline Eclipta alba (L.) Hassk. & - & - & Sorghum halepense (L.) Pers. & - & - \\
\hline Eclipta prostrata (L.) L. & 0.05 & 0.37 & Spermacoce tenuior L. & - & - \\
\hline Eichornia crassipes (Martius) Solms & - & - & Spigelia anthelmia $\mathrm{L}$. & 0.01 & - \\
\hline Eleusine indica (L.) Gaertn. & - & - & Stemodia durantifolia (L.) Sw. & - & 0.25 \\
\hline Emilia fosbergii Nicolson & - & - & Torulinium odoratum (L.) S. S. Hooper & - & - \\
\hline Euphorbia heterophylla L. & 0.01 & - & Trianthema portulacastrum $\mathrm{L}$. & 0.28 & 0.70 \\
\hline Galinsoga parviflora Cav. & - & - & Tridax procumbens $\mathrm{L}$. & 0.11 & 16.09 \\
\hline Gomphrena serrata $\mathrm{L}$. & - & - & Typha sp. & 0.01 & 0.50 \\
\hline Heliotropium indicum $\mathrm{L}$. & 0.01 & 0.11 & Urochloa fasciculata Kunth & 0.11 & 0.86 \\
\hline Heliotropium procumbens Mill. & - & - & Urochloa mollis (Sw.) Morrone \& Zuloaga & - & - \\
\hline Herissantia crispa (L.) Brizicky & - & - & Urochloa reptans (L.) Stapf & - & - \\
\hline Heteranthera limosa (Sw.) Willd. & - & - & Vigna vexillata (L.) A. Rich. & - & - \\
\hline Hymenachne amplexicaulis (Rudge) Nees & - & - & Waltheria indica L. & - & - \\
\hline
\end{tabular}

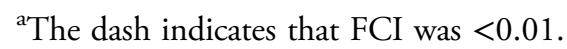


weed diversity might be highly influenced by agricultural management and not so much by landscape plant diversity (Armengot et al. 2011; Bohan and Haughton 2012; Guerrero et al. 2014).

Approximately $20 \%$ of the species had an FCI from 0.01 to 0.10 (Table 2). Farm managers and agronomists responsible for the evaluated fields considered that weed species within this FCI range are observed frequently, but their cover levels are low enough that they do not affect weed control decisions (unpublished data). Conversely, 19\% of the species exhibited an FCI between 0.10 and 0.55 . In this group, frequency and cover levels were high enough to influence weed control decisions, such as timing, for herbicide applications and cultivation. However, farm managers and agronomists indicated that species that exhibited an FCI $\geq 0.55$ (representing $10 \%$ of the total weed diversity observed) would likely need specific weed control actions (e.g., extra herbicide applications or the use of specific herbicides) to avoid crop yield loss.

\section{Differentiation among Management Areas.}

There was a significant interaction between year and management area for weed species richness $(\mathrm{P}<0.002)$, so the results of the 1998 and 2000 surveys were analyzed separately.

In 1998 the border was the most diverse management area, with richness values double those observed in row and furrow (Figure 2). The other management areas had intermediate richness. In 2000 a similar pattern was observed, but weed species richness in the row was higher than in the furrow, which was the management area with the lowest values. Despite the turn area being one of the most disturbed management areas, weed species richness there was similar to that in the border in both years.

Solé-Senan et al. (2014) recently determined that richness of rare arable plants in agricultural fields is highly influenced by landscape complexity, and this effect is more prevalent in borders than in the centers of the fields because of survival filters that are imposed with agricultural management, but the influence of landscape heterogeneity on weed diversity is limited to short distances from the agricultural field (Gaba et al. 2010). Thus, borders not only could favor higher weed diversity but also could be a reservoir of rare species present in other parts of the landscape that will not necessarily affect the management of the crop. In our study, weed richness in the border (seven and nine weed species in 1998 and 2000, respectively) almost doubled that in row and furrow, similar to the trend observed in grain fields in Argentina

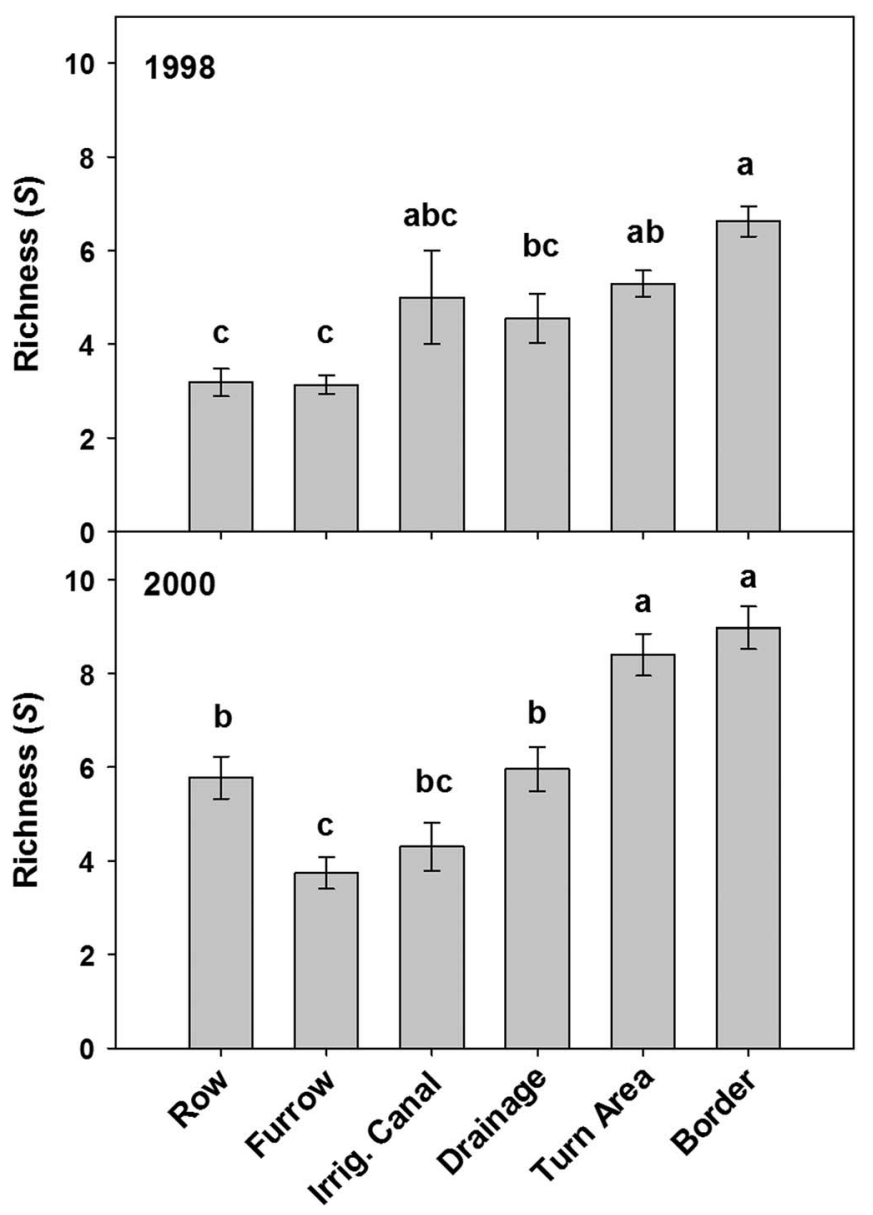

Figure 2. Weed species richness in five management areas in sugarcane fields in Cañas, Guanacaste, Costa Rica, in 1998 and 2000. Error bars represent SEM, and bars with different letters are statistically different based on Tukey-Kramer HSD $(\alpha=0.05)$.

reported by Poggio et al. (2013) and in the northeast Iberian Peninsula by José-María et al. (2010), in which richness outside fields was two to four times higher than in the centers of fields, depending on the cropping system. These researchers also concluded that in field edges, weed species richness was intermediate between the centers of the fields and the borders. It is worth noting that, in general, weed richness in each management area was low (i.e., $<10$ species) (Figure 2), although total weed richness was high (i.e., 120 species). One possibility is that most of the weed diversity depends on rare species. However, this is unlikely, because as mentioned before, $49 \%$ of the species had FCI values $>0.01$ and were found relatively frequently. It is more likely that spatial heterogeneity favoring $\beta$-diversity could explain the overall weed diversity observed in the present study (Poggio et al. 2010). Thus, agricultural practices might limit the total number of weed species present in a given field and/or management area, but 
differences among fields in weed community composition is a driving factor of the overall weed diversity in the sugarcane cropping system.

In our study, the irrigation canal and drainage presented intermediate richness (Figure 2), but the turn area, which was equivalent to field edges in Poggio et al. (2013) and José-María et al. (2010), consistently exhibited the same weed richness as the border. This is particularly interesting, because our original hypothesis was that weed diversity would be negatively affected by the intensity of the disturbance caused by agricultural management (Hawes et al. 2010). The turn area received herbicides, fertilizer, cultivation, and sugarcane-planting practices almost as intense as the row and furrow. Higher weed species richness in the turn area than in the row and furrow might be explained by slightly lower intensity of agricultural practices (Kleijn and van der Voort 1997; Romero et al. 2008). For example, because tractors do not necessarily apply herbicides or fertilizers exactly from the edge of the field, due to the need to start their runs in the turn area (i.e., accelerating area), herbicide and fertilizer rates tend to be lower in the turn area than in the row and furrow. However, the turn area had more traffic, which caused more physical damage to emerged weeds and more soil compaction. Therefore, the turn area was one of the most disturbed management areas in the study. This finding might be the result of a trade-off between weed mortality and resources for weed growth (Musters et al. 2009) and the potential increase in weed trait diversity that can be favored by disturbance (Grime 2006; Hernández Plaza et al. 2015). In less disturbed environments such as grasslands, the application of herbicides and fertilizer has a negative impact on plant richness (Kleijn and van der Voort 1997; Storkey et al. 2015), but nutrient addition can greatly favor species that can take advantage of those nutrients (Kleijn and Snoeijing 1997). Light penetration in agricultural fields has also been positively associated with species richness (Kleijn and van der Voort 1997; Seifert et al. 2014). Furthermore, disturbances created by agricultural practices could result in new niches by providing new resources through elimination of established, more competitive species (Hernández Plaza et al. 2015). Although weed control was more intensive in the turn area than in other management areas, this area had higher fertility (e.g., several fertilizer applications) than the irrigation canal and drainage and more light than the row and furrow because it was the crop area closest to the edge of the field (Kleijn and van der Voort 1997). Additionally, soil compaction would have played a key role in maintaining moisture for longer times in loam and sandy loam soils, which in the dry tropics is critical, especially during the dry season (when this survey was conducted) to favor weed seed germination and plant growth. Our results suggest that disturbance, and especially weed control practices are major drivers of weed diversity in sugarcane cropping systems, but availability of resources for weed growth, such as nutrients, soil moisture, and light, can mitigate some of the limitations imposed by weed control on weed diversity.

\section{Weed Community Structure and Management}

Area. In 1998, based on frequency of detection, differentiation in weed community structure among management areas was significant $(\mathrm{P}<0.01)$, but it was small and determined by a few species (Figure 3 ). Most weed species were evenly distributed among management areas, with no clear preference. Conversely, in 2000 management areas exhibited evident differentiation in weed community structure $(\mathrm{P}=0.0002)$. Thus, species such as common purslane (Portulaca oleracea L.), stipulate leaf-flower [Phyllanthus stipulatus (Raf.) GL Webster], and desert horsepurslane (Trianthema portulacastrum L.) were positively associated with the row and furrow, while bermudagrass [Cynodon dactylon (L.) Pers.] and least snoutbean [Rhynchosia minima (L.) DC.] exhibited a negative relation with these management areas.

Weed community structure followed pattern similar to weed species richness, and management areas with similar disturbance levels had similar weed community composition (Figure 3). Thus, the row was similar to the furrow and the irrigation canal to drainage. However, the weed community composition of the row and furrow differed from that observed in the irrigation canal and drainage, and all these management areas differed from the border (i.e., right angles in the biplot). The turn area also exhibited a unique behavior, with no evident weed community differentiation compared with the other management areas, making this management area the most representative of weed diversity between the border and other management areas. Most of the predominant weed species exhibited a generalist behavior, with no clear preference for specific management areas (i.e., located close to the center of the biplot).

Weed Community Structure and Soil Texture. No interaction between year and soil type was detected for weed species richness $(\mathrm{P}>0.90)$, so the results of both years were pooled for the analysis. Conversely, community structure varied depending 

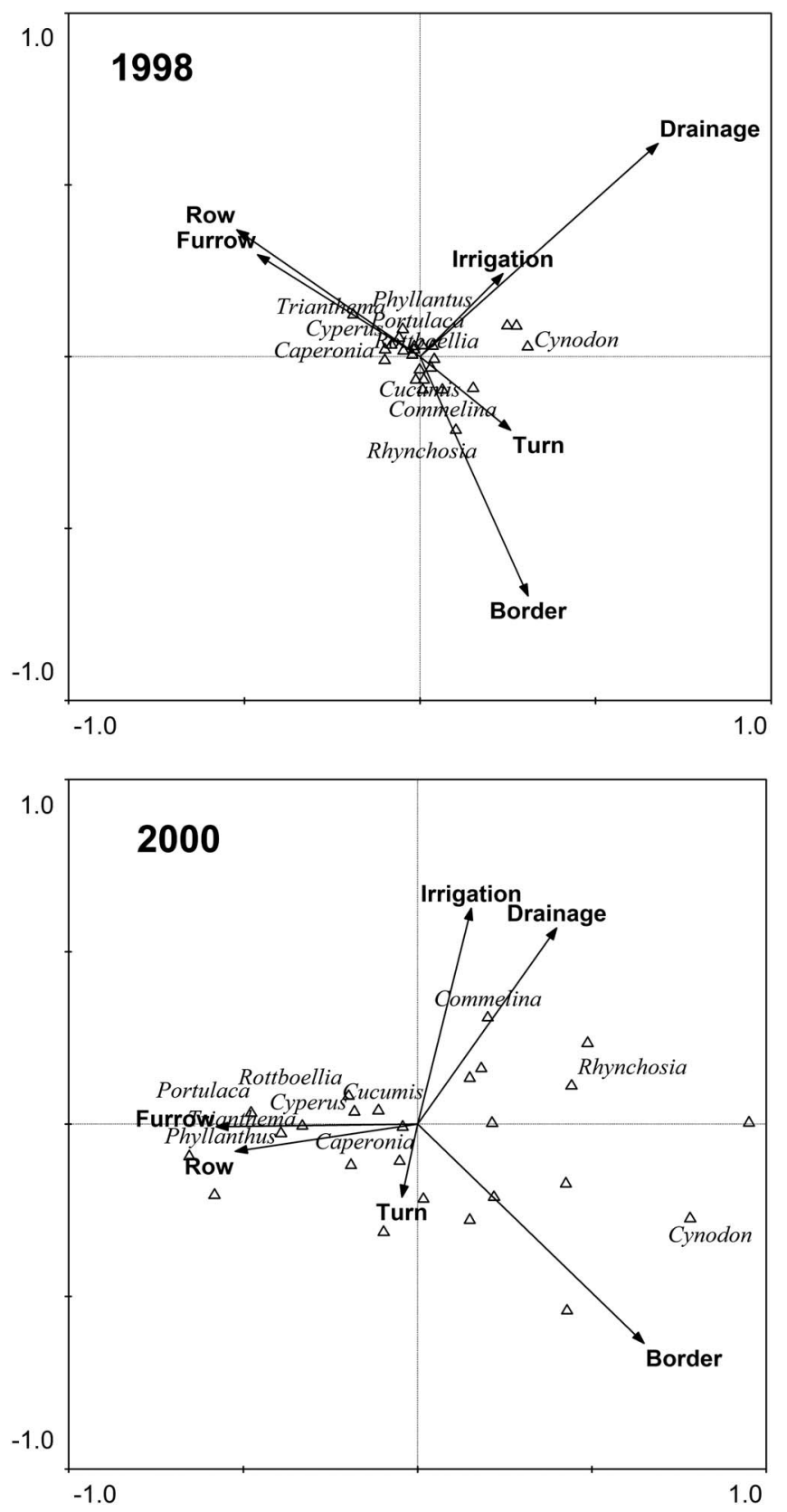

Figure 3. Canonical correspondent analysis describing the relation between the $25 \%$ most frequent weed species and five management areas in sugarcane fields in Cañas, Guanacaste, Costa Rica, in 1998 and 2000. Axes explained 70 and $83 \%$ variance of total inertia for 1998 and 2000, respectively.

on the year, so this analysis was conducted separately by year.

Soil type did not affect richness $(\mathrm{P}>0.95)$, suggesting that the evaluated soil textures supported the same level of weed species diversity. Community structure differentiation was more evident in response to soil type (Figure 4) compared with management area (Figure 3). For example, weed communities in clay soil consistently included texasweed [Caperonia palustris (L.)
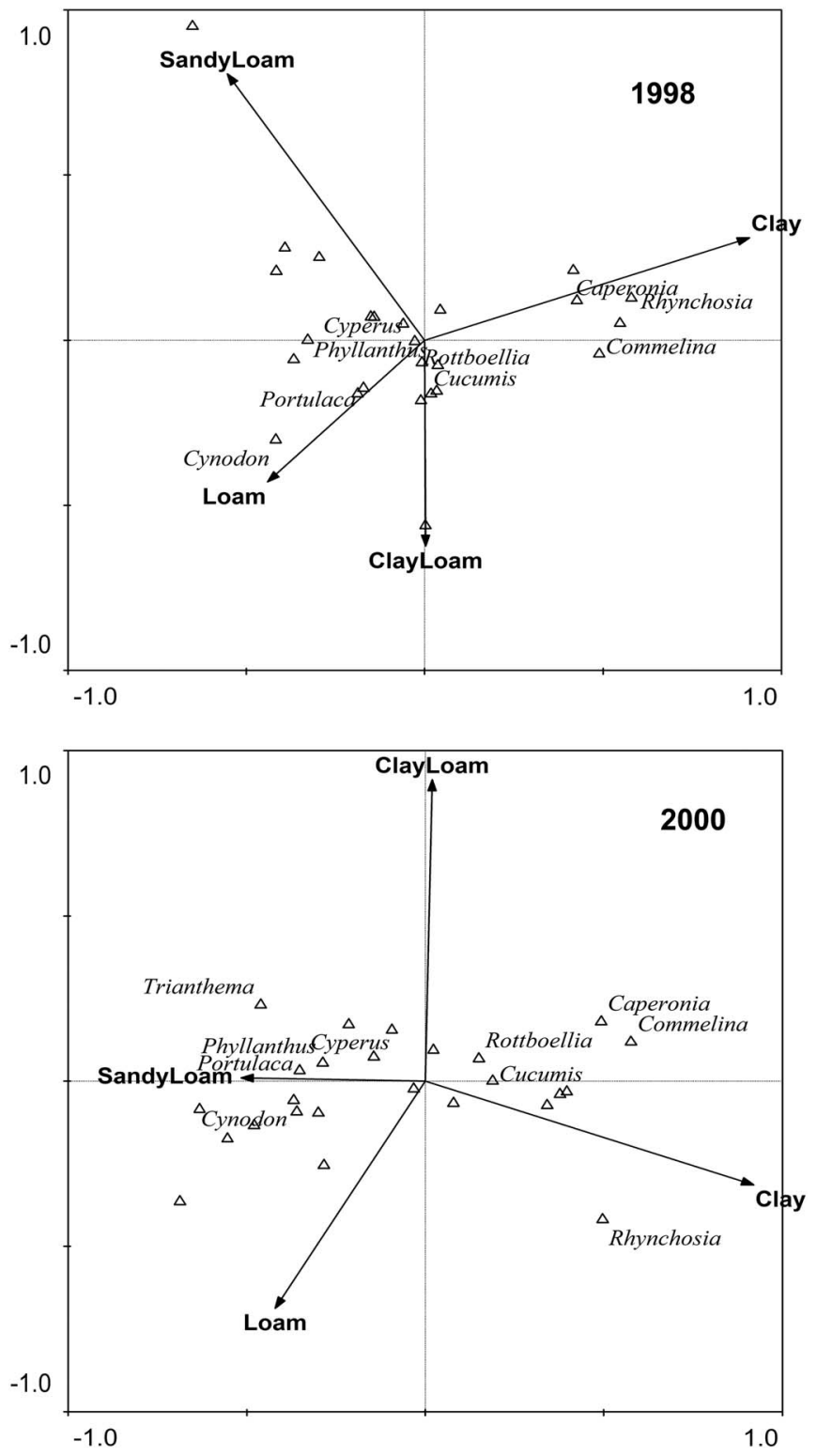

Figure 4. Canonical correspondent analysis describing the relation between the $25 \%$ most frequent weed species and four soil textures in sugarcane fields in Cañas, Guanacaste, Costa Rica, in 1998 and 2000. Axes explained 87 and 95\% variance of total inertia for 1998 and 2000, respectively.

A. St.-Hil.], asiatic dayflower (Commelina diffusa Burm. F.), and least snoutbean in both years. These species were negatively related to coarser soil textures such as loam and sandy loam, for which there was a positive relation with bermudagrass, purple nutsedge (Cyperus rotundus L.), stipulate leaf-flower, and common purslane. Weed species with high FCI in both years, such as itchgrass [Rottboellia cochinchinensis (Lour.) Clayton] and smellmelon (Cucumis melo L.) (Table 2), were not strongly associated with any specific soil texture and were close to the centers of the biplot (Figure 4). 
Soil characteristics are important determinants of weed community assembly, with clay content being one of the most important (Andreasen and Skovgaard 2009; Fried et al. 2008; Grime 1979; Hawes et al. 2010). Andreasen et al. (1992) determined that detection frequency can be negatively or positively related to clay content depending on the species. In the present study, most of the evaluated species preferred loam and sandy loam soils, but there were species such as stipulate leafflower, spreading dayflower, and least snoutbean that were associated with clay soils, suggesting that differences among species in soil moisture requirements might influence weed community composition in the dry tropics and that species with high water requirements will be more closely related with finer textures. However, most of the predominant weeds either showed no preference (i.e., were close to the center of the biplot) or preferred loam and sandy loam soils.

\section{Distribution of Weed Species of Economic} Importance. We selected six weed species (highest FCI values and considered of economic importance by farm managers) to determine whether these species are generalists or could develop larger populations in specific management areas and soil types, which would justify the use of differentiated control tactics. For this analysis, we compared the cover index of these weed species, excluding fields in which they were absent (i.e., only fields with cover $>1$ were considered).

Although weed species with high FCI values were present in all management areas (Figure 5), some of them developed larger populations in specific management areas. Additionally, it seems that aggressive weed species are not necessarily generalists. For example, itchgrass and purple nutsedge were considered the most economically important and the most difficult to control weed species by farm managers and agronomists, and this perception was in agreement with the observed FCI values, which made these the top two weed species in both years (Table 2). While itchgrass exhibited a mean cover index around 2.25 for all management areas, purple nutsedge exhibited cover indexes that were at least $67 \%$ higher in the drainage compared with the row, and 27 to $46 \%$ higher in the drainage than the other management areas (Figure 5). As observed in itchgrass, smellmelon and texasweed exhibited cover indexes that were similar among management areas. In contrast, spreading dayflower populations differed between management areas, with the furrow being the least favorable management area for this species, with cover values that represented a 41,58 , and $53 \%$ reduction compared with the border, irrigation canal, and drainage, respectively. Least snoutbean formed populations that ranged between 1.0 and 1.7 in most management areas, with the exception of drainage, in which the cover index was 44 to $160 \%$ higher than the other management areas.

Preferences in soil texture measured by cover index were also observed (Figure 6, P < 0.01). Asiatic dayflower and least snoutbean exhibited the same cover regardless of soil texture. Itchgrass had smaller populations in fields with sandy loam soil compared with the other three soil types. Purple nutsedge cover increased as soil texture became coarser, while smellmelon exhibited the opposite behavior. Texasweed developed larger populations in fields with clay soil compared with fields with loam soil, but a clear relation between soil texture and cover index was not observed.

Although the results seem to indicate that weed community structure will be determined by water requirements of the species and water availability in the field, our results indicate a more complex process. When we evaluated in more detail the size of the populations of the most predominant species, not all weed species that were consistently associated with clay soils showed differences in cover depending on soil texture. For example, asiatic dayflower and snoutbean were associated with clay soils based on detection frequency (Figure 4), but the cover they exhibited did not differ between soil types (Figure 6). Interestingly, these two weed species formed larger populations in management areas with less disturbance and higher water inputs and retention, such as the irrigation canal and drainage (Figure 5). Texasweed and smellmelon exhibited the opposite behavior. These two species formed larger populations in finer than in coarser soil textures (Figure 6), but their cover did not differ among management areas.

Weed Management and Biodiversity. Differences in weed communities between management areas within fields were not high enough to justify the use of unique weed control tools targeting specific species. However, these differences might enable better allocation of resources for weed control. Furthermore, soil type preferences, although they do not necessarily enable a specific weed management, can be used to anticipate population growth of key weed species and help determine when and where 


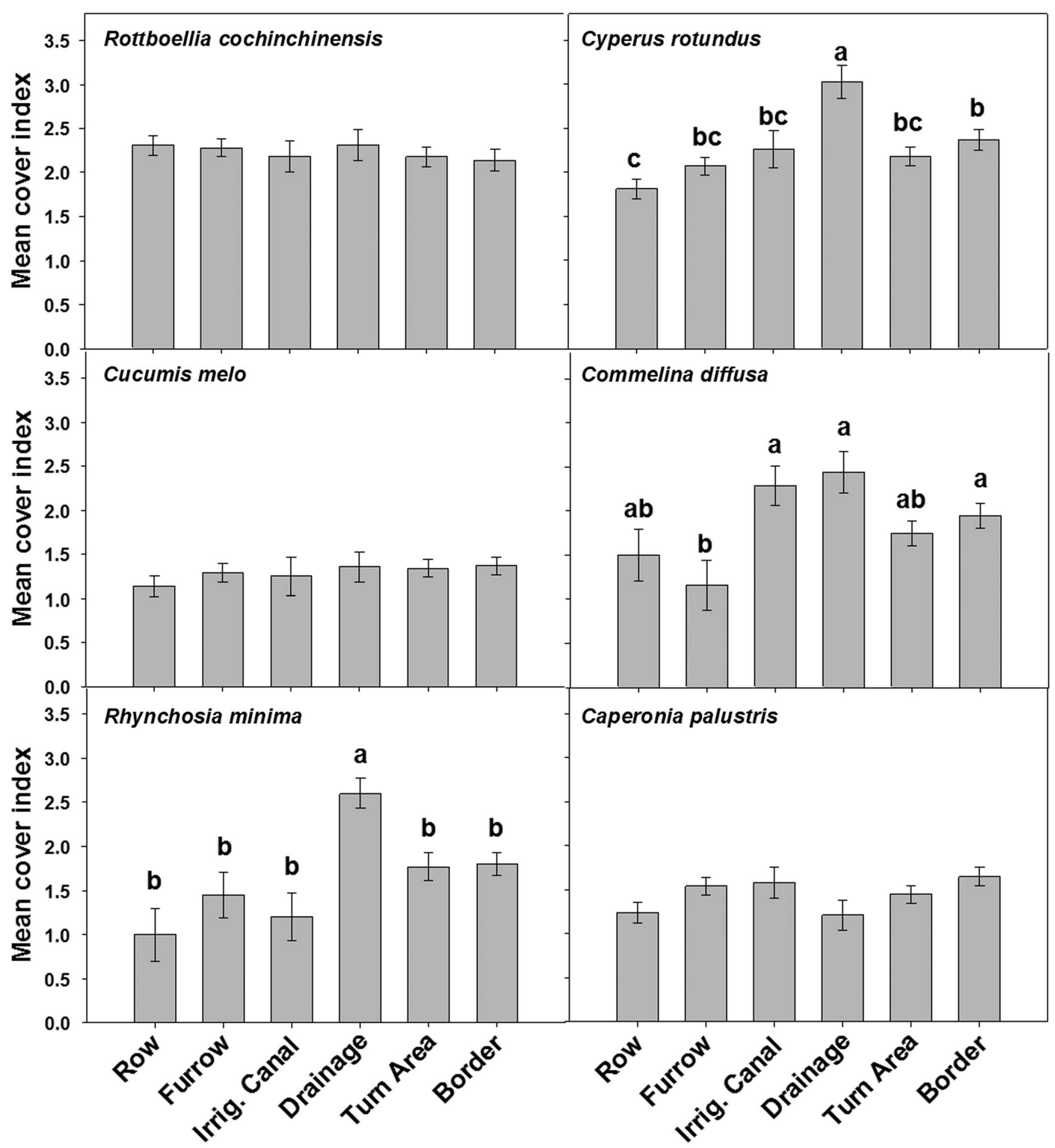

Figure 5. Population size (cover index) of six predominant weed species in five management areas in sugarcane fields in Cañas, Guanacaste, Costa Rica. Error bars represent SEM, and bars with different letters are statistically different based on Tukey-Kramer HSD $(\alpha=0.05)$. Data are the averages of the 1998 and 2000 surveys.

more intensive control should be implemented to reduce weed population growth. In other words, these results allow identification of areas with higher risk of population increases for specific weed species (e.g., sandy loam and drainage for purple nutsedge).
Our survey describes spatial distribution preferences based on frequency and cover for weed species, but how individuals move between management areas is not known. It is still necessary to determine whether populations of weeds of economic 


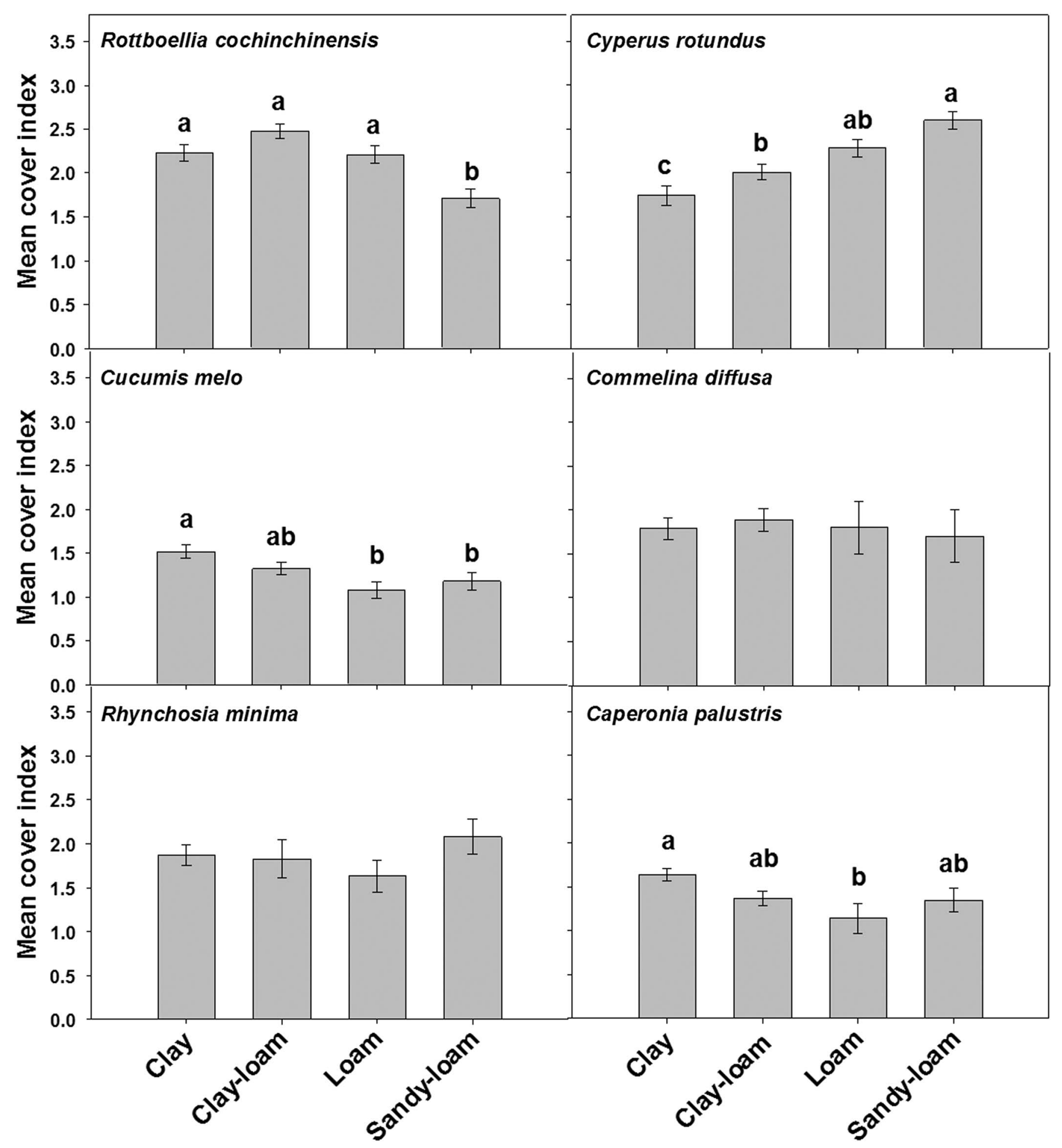

Figure 6. Population size (cover index) of six predominant weed species in four soil textures in sugarcane fields in Cañas, Guanacaste, Costa Rica. Error bars represent SEM, and bars with different letters are statistically different based on Tukey-Kramer HSD ( $\alpha=0.05)$. Data are the averages of 1998 and 2000 surveys.

importance in the border, turn area, or irrigation canal that do not affect sugarcane yield contribute seed/propagules to the row and furrow, potentially helping to perpetuate weed interference within the field. If this is the case, growers might need to intensify weed control in the former management areas, decreasing their role as biodiversity-preserving areas, or they might need to develop strategies to prevent that influx of weeds into the field without reducing weed diversity outside the field.

The present study indicated that spatial variability in sugarcane cropping systems plays an important

138 - Weed Science 65, January-February 2017 
role in maintaining weed diversity and that although the most economically important weed species can be present in all management areas, less frequently occurring species will be distributed differently among management areas. As reported by other studies, field borders are particularly important in maintaining weed diversity because of the lower disturbance present in those areas compared with within the field. However, the fact that the turn area, which was one of the most disturbed management areas in our study, had weed species richness similar to the border highlights the importance of considering resource availability and its effect on weed growth to compensate for the limitations imposed by disturbance associated with crop management.

\section{Acknowledgments}

We thank Ingenio Taboga for the financial and logistic support provided to conduct the present study. Also, we are grateful for the technical advice provided by Roberto Mayorga, Edgar Vega, and Mario Berrocal during the data-collection phase of the study and for the technical assistance provided by Neeta Soni and Rocio van der Laat during data processing.

\section{Literature Cited}

Andreasen C, Skovgaard IM (2009) Crop and soil factors of importance for the distribution of plant species on arable fields in Denmark. Agric Ecosyst Environ 133:61-67

Andreasen C, Jensen JE, Streibig JC (1992) Weed communities described by multivariate analysis. Pages 50-54 in Proceedings of the First International Weed Control Congress. Melbourne, Australia: Weed Science Society of Victoria

Armengot L, José-María L, Blanco-Moreno JM, Romero-Puente A, Sans FX (2011) Landscape and land-use effects on weed flora in Mediterranean cereal fields. Agric Ecosyst Environ 142:311-317

Bertsch F (1995) La fertilidad de los suelos y su manejo. 1st edn. San José, Costa Rica: Asociación de la Ciencia del Suelo. 157 p

Blackshaw RE, Molnar LJ, Janzen HH (2004) Nitrogen fertilizer timing and application method affect weed growth and competition with spring wheat. Weed Sci 52:614-622

Bohan DA, Haughton AJ (2012) Effects of local landscape richness on in-field weed metrics across the Great Britain scale. Agric Ecosyst Environ 158:208-215

Cordeau S, Petit S, Reboud X, Chauvel B (2012) The impact of sown grass strips on the spatial distribution of weed species in adjacent boundaries and arable fields. Agric Ecosyst Environ 155:35-40

de Rouw A, Casagrande M, Phaynaxay K, Soulileuth B, Saito K (2014) Soil seedbanks in slash-and-burn rice fields of northern Laos. Weed Res 54:26-37

Fried G, Norton LR, Reboud X (2008) Environmental and management factors determining weed species composition and diversity in France. Agric Ecosyst Environ 128:68-76
Gaba S, Chauvel B, Dessaint F, Bretagnolle V, Petit S (2010) Weed species richness in winter wheat increases with landscape heterogeneity. Agric Ecosyst Environ 138:318-323

Grime JP (1979) Plant Strategies and Vegetation Processes. Chichester, UK: Wiley. $222 \mathrm{p}$

Grime JP (2006) Trait convergence and trait divergence in herbaceous plant communities: mechanisms and consequences. J Veg Sci 17:255-260

Guerrero I, Carmona CP, Morales MB, Ońate J, Peco B (2014) Non-linear responses of functional diversity and redundancy to agricultural intensification at the field scale in Mediterranean arable plant communities. Agric Ecosyst Environ 195:36-43

Hawes C, Squire GR, Hallett PD, Watson CA, Young M (2010) Arable plant communities as indicators of farming practice. Agric Ecosyst Environ 138:17-26

Hernández Plaza E, Navarrete L, González-Andújar JL (2015) Intensity of soil disturbance shapes response trait diversity of weed communities: the long-term effects of different tillage systems. Agric Ecosyst Environ 207:101-108

Holdridge L (1982) Ecología basada en zonas de vida. 1st edn. San José, Costa Rica: Interamerican Institute for Cooperation on Agriculture. $216 \mathrm{p}$

José-María L, Armengot L, Blanco-Moreno JM, Bassa M, Sans FX (2010) Effects of agricultural intensification on plant diversity in Mediterranean dryland cereal fields. J Appl Ecol 41:832-840

Kamoshita A, Araki Y, Nguyen YTB (2014) Weed biodiversity and rice production during the irrigation rehabilitation process in Cambodia. Agric Ecosyst Environ 194:1-6

Kleijn D, Snoeijing GIJ (1997) Field boundary vegetation and the effects of agrochemical drift: botanical change caused by low levels of herbicide and fertilizer. J Appl Ecol 34:1413-1425

Kleijn D, van der Voort LAC (1997) Conservation headlands for rare arable weeds: the effects of fertilizer application and light penetration on plant growth. Biol Conserv 81:57-67

Marshall EJP, Brown VK, Boatman ND, Lutman PJW, Squire GR, Ward LK (2003) The role of weeds in supporting biological diversity within crop fields. Weed Res 43:77-89

Mittermeier RA, Myers N, Thomsen JB, da Fonseca GAB, Olivieri S (1998) Biodiversity hotspots and major tropical wilderness areas: approaches to setting conservation priorities. Conserv Biol 12:516-520

Mortensen DA, Egan JF, Maxwell BD, Ryan MR, Smith RG (2012) Navigating a critical juncture for sustainable weed management. BioScience 62:75-84

Musters CJM, van Alebeek F, Geers RHEM, Korevaar H, Visser A, de Snoo GR (2009) Development of biodiversity in field margins recently taken out of production and adjacent ditch banks in arable areas. Agric Ecosyst Environ 129: 131-139

Norris RF, Kogan M (2000) Interactions between weeds, arthropod pests, and their natural enemies in managed ecosystems. Weed Sci 48:94-158

Olson DM, Dinerstein E, Wikramanayake ED, Burgess ND, Powell GVN, Underwood EC, D’Amico JA, Itoua I, Strand HE, Morrison JC, Loucks CJ, Allnutt TH, Ricketts TH, Kura Y, Lamoreux JF, Wettengel WW, Hedao P, Kassem KR (2001) Terrestrial ecoregions of the world: a new map of life on Earth. BioScience 51:934-938

Perfecto I, Vandermeer J (2010) The agroecological matrix as alternative to the land-sparing/agriculture intensification model. Proc Nat Acad Sci USA 107:5786-5791 
Petit S, Alignier A, Colbach N, Joannon A, Le Coeur D, Thenail C (2011) Weed dispersal by farming at various scales. A review. Agron Sustain Dev 33:205-217

Poggio SL, Chaneton RJ, Ghersa CM (2010) Landscape complexity differentially affects alpha, beta, and gamma diversities of plants occurring in fencerows and crop fields. Biol Conserv 143:2477-2486

Poggio SL, Chaneton RJ, Ghersa CM (2013) The arable plant diversity of intensively managed farmland: effects of field position and crop type at local and landscape scales. Agric Ecosyst Environ 166:55-64

Rojas M (1995) Estudio de las malezas asociadas a canales de riego y zonas aledańas del cultivo de arroz anegado en el Distrito de Riego Arenal-Tempisque y combate biológico de Hydrilla verticillata Vahl. con carpa herbívora (Ctenopharygodon idella Via.). M.Sc. thesis. San José, Costa Rica: University of Costa Rica. $218 \mathrm{p}$

Romero A, Chamorro L, Sans FX (2008) Weed diversity in crop edges and inner fields of organic and conventional dryland winter cereal crops in NE Spain. Agric Ecosyst Environ 124:97-104

Seifert C, Leuschner C, Meyer S, Culmsee H (2014) Interrelationships between crop type, management intensity and light transmissivity in annual crop systems and their effect on farmland plant diversity. Agric Ecosyst Environ 195:173-182

Solé-Senan XO, Juárez-Escario A, Conesa JA, Torra J, Royo-Esnal A, Recasens J (2014) Plant diversity in
Mediterranean cereal fields: unraveling the effect of landscape complexity on rare arable plants. Agric Ecosyst Environ $185: 221-230$

Soto A, Agüero R (1992) Combate químico de malezas en arroz. 1st edn, San José, Costa Rica: Editorial Universidad de Costa Rica. $81 \mathrm{p}$

Storkey J, Cussans JW (2007) Reconciling the conservation of infield biodiversity with crop production using a simulation model of weed growth and competition. Agric Ecosyst Environ 122:173-182

Storkey J, Macdonald AJ, Poulton PR, Scott T, Kohler IH, Schnyder H, Goulding KWT, Crawley MJ (2015) Grassland biodiversity bounces back from long-term nitrogen addition. Nature 528:401-404

Sutton KF, Lanini WT, Mitchell JP, Miyao EM, Shresta A (2006) Weed control, yield, and quality of processing tomato production under different irrigation, tillage, and herbicide systems. Weed Technol 20:831-838

Trichard A, Alignier A, Chauvel B, Petit S (2013) Identification of weed community traits response to conservation agriculture. Agric Ecosyst Environ 179:179-186

Received May 1, 2016, and approved August 28, 2016.

Associate Editor for this paper: Steven S. Seefeldt, USDA-ARS. 